\title{
Empowering Smallholder Women Farmers through Participatory Seed Potato Management: Lessons from Welmera District, Ethiopia
}

\author{
Ali Mohammed Oumer ${ }^{1}$, Wudineh Getahun Tiruneh ${ }^{1} \&$ Chilot Yirga Tizale ${ }^{1}$ \\ ${ }^{1}$ Ethiopian Institute of Agricultural Research (EIAR), Holetta Agricultural Research Center, Addis Ababa, \\ Ethiopia \\ Correspondence: Ali Mohammed Oumer, Department of Agricultural Economics, Research Extension and \\ Farmer Linkage (AEREFL); Ethiopian Institute of Agricultural Research (EIAR), Holetta Agricultural Research \\ Center, P.O. Box 2003, Addis Ababa, Ethiopia. E-mail: alioumer@gmail.com
}

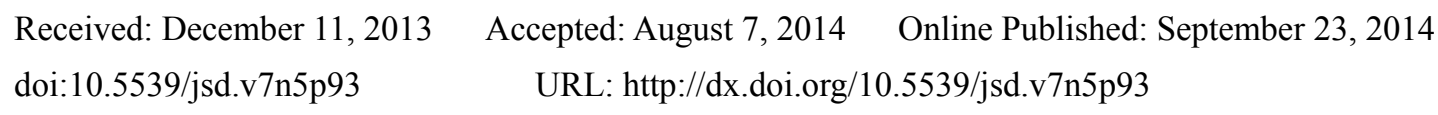

\begin{abstract}
Women are often ignored from research and development agenda although they play key roles in agriculture in developing countries. They are excluded from decision making and as a result, they frequently do not have access to resources, technologies and extension services, credits, inputs and markets. This paper aims to document, using qualitative methods, how participatory approach through Farmers Research Group (FRG) can address gender inequalities and subsequently empower women smallholder farmers using a case study from Ethiopia. Through the participatory intervention, women farmers have enhanced their skills and knowledge of improved agricultural technologies as well as their collective capacity (social capital) in accessing input and output markets. As a result, the number of FRG members increased from 25 women farmers organized in one FRG in 2006 to 253 women farmers organized in 11 village-level Farmers Research Extension Groups (FREGs) in 2013. The participatory intervention in the study area has improved women's productivity of seed potatoes and marketing; enabled them to earn cash an average of Ethiopian Birr (ETB) 11000 per year only from the sale of seed potatoes; and this has created more options to improve the livelihoods of women farmers and their households by diversifying into higher-value farm and off-farm work. Consequently, women decision making in the household as well as in the community has been enhanced. Women farmers are now heard at national level for their innovative experiences and have become one of the national seed potato and knowledge sources. There is a need to replicate this model approach to enhance the productivity of smallholder women farmers and subsequently empower them to facilitate exit pathways out of poverty and ensure sustainable development.
\end{abstract}

Keywords: participatory approach, farmer group, seed potato, social capital, women empowerment

\section{Introduction}

Women are critical component of agriculture in developing countries with a significant share of the agricultural labour force. They comprise approximately $70 \%$ of sub-Saharan Africa (SSA) agricultural workers and account for about $80 \%$ of food processors (Wakhungu, 2010). However, they are ignored from research and development agenda; being recognized as not 'productive' farmers as many speculate their reproductive roles outweigh. Their farm work is usually unpaid or under-valued; they are excluded from decision making and as a result, they do not have equal access to resources, credits, markets, inputs, technologies and extension services as compared to men (World Bank, 2007; Food and Agriculture Organization of the United Nations [FAO], 2011). Narrowing these gender inequalities including intra-household gender dynamics, undoubtedly, would empower women farmers and can have significant social and economic impacts (Quisumbing \& Pandolfelli, 2010; Alkire et al., 2013).

In the central highlands of Ethiopia, one of the approaches that has the potential to empower women and enhance farmer participation has been participatory research through improved seed potato production. This was very crucial to marginalized women farmers who have been engaged in subsistence cereal production. Seed potato production (Note 1) is a market-oriented agricultural enterprise in which farmers use improved agronomic techniques for potato production. Seed potato production is an attractive option to improve productivity of women farmers as it saves their 'unproductive' labour used for subsistence cereal production. Contrarily, conventional research and extension approach has resulted in limited adoption of agricultural technologies 
(Bedane \& Kuma, 2002; Tesfaye, Yirga, \& Bekele, 2002) and further deepened the gender gaps in agricultural production. The limited adoption has been attributed to the top-down approach to technology generation and transfer with marginal farmer involvement particularly women farmers. While conventional research is indeed necessary for basic agricultural sciences, there is a need to acknowledge the importance of farmer participation that can enhance social capital especially of marginalized women farmers (in technology development and transfer) in order to empower them to exit out of chronic poverty.

The Ethiopian Agricultural Research System (EARS) has therefore passed through different phases of participatory research approaches, each with its own contributions and limitations. According to Tesfaye et al. (2002) those phases included: (i) Package Testing and Multidisciplinary Survey Approach (1975-1983), (ii) Farming Systems Approach (1984-1998), and (iii) Client-oriented Research Approach (1999-to the present). The client-oriented research approach further evolved into Farmers Filed School (FFS), Farmers Research Group (FRG) and Farmers Research Extension Group (FREG) depending on the degree of farmer involvement, level of farmer participation and gender inclusiveness. Due to its scope for interactive farmer participation, gender inclusiveness, empowerment of farmer for agricultural innovation and potential for linking farmers with other stakeholders; the FRG approach is widely practiced at the moment and getting momentum in different parts of Ethiopia including our case study area. More recently, efforts are being made to institutionalize the FRG approach in the EARS (Bedru et al., 2009) although there are a number of challenges in the process.

In this article, we aim to contribute to an increased understanding of how participatory seed potato management organized in the form of FRG can empower women smallholder farmers. We documented how the participatory process has been working and who is mainly benefiting from the process. We also outlined key challenges and lessons learnt for possible replication of the approach in Ethiopia as well as in other SSA countries. This can provide a better understanding of how gender-sensitive interventions work on the ground and help design suitable policy tools toward women smallholder farmers. This should also contribute to global initiatives narrowing gender gaps in agricultural development to ensure food security and sustainable development. We analysed and documented evolving participatory processes and women farmer innovations to provide input for practical policy making addressing gender inequalities.

\section{Materials and Methods}

\subsection{The Study Area and the Research Context}

The study was conducted at Burkusame Gebiya Robe kebele (Note 2) administration. It is one of the 23 rural kebele administrations in Welmera district in the central highlands of Ethiopia. It is located about ten kilometers from Holetta town, the capital of the district (Figure 1). The kebele is sub-divided into nine villages. The area is characterized as barley based crop-livestock farming system of the upper highlands ( $>2600$ m.a.s.l) where barley, wheat, tef, and lately potato are the major crops grown. The area is also characterized by its degraded soils and farmers have been using local varieties and poor agronomic practices. As the Ethiopian highlands are densely populated, farm sizes are shrinking and have become a challenge to support an extensive mode of cereals production in the region. Women farmers were predominately engaged in subsistence cereal production and options to move into higher-value market-oriented production were very limited. Improved potato production can contribute to income generation in an ever-shrinking farm sizes in the Ethiopian highlands as the revenue from potato can be as much as ten times greater than the revenue from grains (Lamaga, 2010).

Farmers in the area used to experience food shortage in the months of July to October (prior to their grain harvest), and female headed households were highly vulnerable to food insecurity and other livelihood shocks (Ayele, Kuma \& Nesha, 2008). During those months, late blight infestation prevented potato production as in many regions of Ethiopia. Yet it is known that potato can give more food, more nutrition and more cash per unit of land and time than would other crops do (Lamaga, 2010). Thus, potato is widely considered a smallholder cash crop of the future and a pathway out of poverty. If women farmers can get disease tolerant potato varieties, they will be able to produce potato in the long rainy season. It means that relatively poorer farmers can have potato harvest prior to grain harvest to overcome food shortages in the months of July to October and at the same time generate cash from the sale of potatoes. 


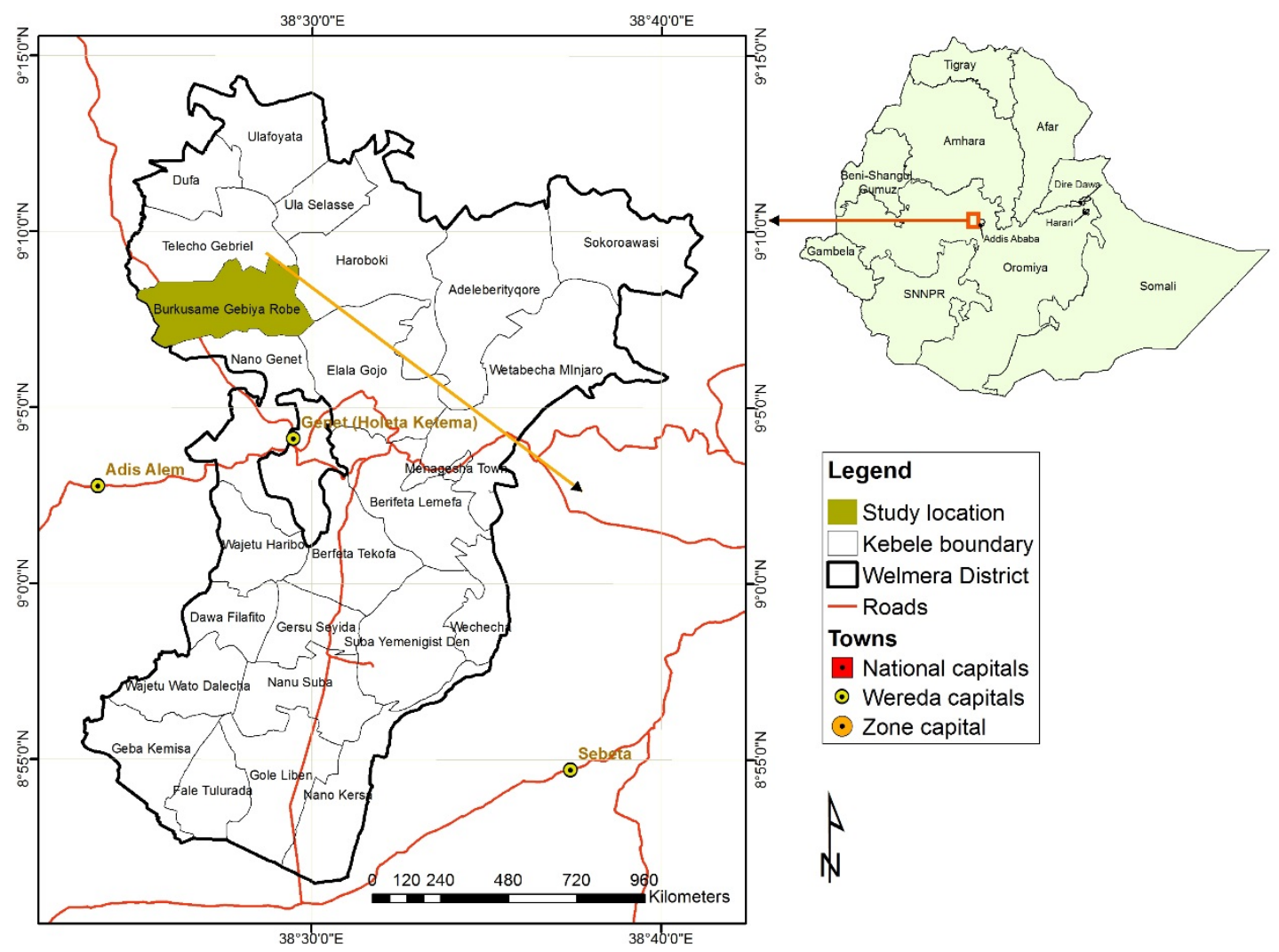

Figure 1. Map of the study area

\subsection{Participatory Action-Oriented Research}

A participatory action-oriented research was adopted in the intervention process, which aids an interactive learning and innovation among stakeholders involved in the participatory FRG intervention. Participatory action research facilitates knowledge transfer and ensures greater farmer participation (e.g., van L. Niekerk \& van D. Niekerk, 2009; Rugumamu, 2014). The study area was selected based on Participatory Rural Appraisal (PRA) survey results and in consultation with district level agricultural experts (Ayele et al., 2008). The interventions were of both technical and organizational nature, which have had evolving processes and innovations over the past eight years. The process will continue as new challenges are emerging that also require new interventions.

\subsubsection{Technical Interventions}

As an entry point in 2006, training was provided for women FRG members on potato production and management techniques including disease protection before distribution of planting materials. Then improved disease tolerant potato varieties with their recommended agronomic packages were delivered to a newly established group of 25 women FRG members using a revolving seed system. Based on the available planting materials, about 1440 seed potato tubers, $6.32 \mathrm{~kg}$ Diaminium Phosphate (DAP) and $5.35 \mathrm{~kg}$ UREA were given for each of the FRG members during planting time. The initial technical intervention packages included: (i) two improved potato varieties namely, Jalene and Gudene, with a yield potential of $29 \mathrm{t} / \mathrm{ha}$ and $45 \mathrm{t} / \mathrm{ha}$, respectively; (ii) recommended agronomic packages of plant spacing of $75 \mathrm{~cm}$ between rows and $30 \mathrm{~cm}$ between plants (about 1440 tubers); (iii) fertilizer rate of $195 \mathrm{~kg}$ DAP and $165 \mathrm{~kg}$ Urea/ha; (iv) recommended post-harvest handling techniques, such as Diffused Light Stores (DLS); and (v) other recommended packages, such as disease control, land preparation and ridging. Fungicide (Ridomil) was sprayed on each of the farmers' plots to control late blight disease. On-station-based trainings and field-based trainings with demonstrations on potato diseases controlling techniques were given to participant farmers during and after planting. A field day was organized to share group experiences to non-intervention farmers around the study area.

\subsubsection{Organizational Interventions}

Organizationally, the initial FRG that embraced 25 interested women farmers was established by the Ethiopian Institute of Agricultural Research (EIAR), Holetta Agricultural Research Center to empower smallholder women 
farmers through seed potato technology in 2006. The FRG initiative was financially supported by the Canadian International Development Agency (CIDA). Women farmers hosted technology evaluation on-farm trials and other fellow farmers outside the intervention area have had access to share information through field days, field visits and farmer-to-farmer interactions. The FRG members were linked with other stakeholders including district level agricultural experts and facilitators. Twenty of the initial FRG members were female headed households. Women member farmers have set a bylaw after discussing about the role of group members in the FRG process. The bylaw was set with the full participation of group members and each group member was accountable and responsible. They elected their chairperson, assistant chairperson, secretary, treasury and auditor The process involved a joint problem identification and FRG design in 2006, which triggered a number of technical and organizational innovations by women smallholder farmers over the past eight years.

\subsubsection{Documenting Evolving Process Innovations}

In this paper, we documented the evolving nature of the participatory interventions from 2006 to 2013. FRG members modified the initial technical and organizational interventions depending on local circumstances and emerging constraints they faced in the process. The evolving processes have resulted in a number of events and attracted many actors that support the processes and engage in "co-investments" in participatory intervention. A summary of those timeline of events is presented in Figure 2. Therefore, to document these evolving participatory processes and farmers' innovations, we employed qualitative social scientific methods (e.g., Chambers, 1993 cited in ICRA, 2013; ICRA, 2013). As participatory research methods, we have put emphasis on documenting the processes, not just results only (Tafur, Hampson, Ingevall \& Thijssen, 2007). We also recognized the value of qualitative data and the information of local people in documenting the processes evolved. We synthesized field-based documented information of the process (Tafur et al., 2007) and triangulated the information by different qualitative data collection methods, such as semi-structured key informant interviews, group discussions, informal discussions with different experts, and participant observations of the case study area.

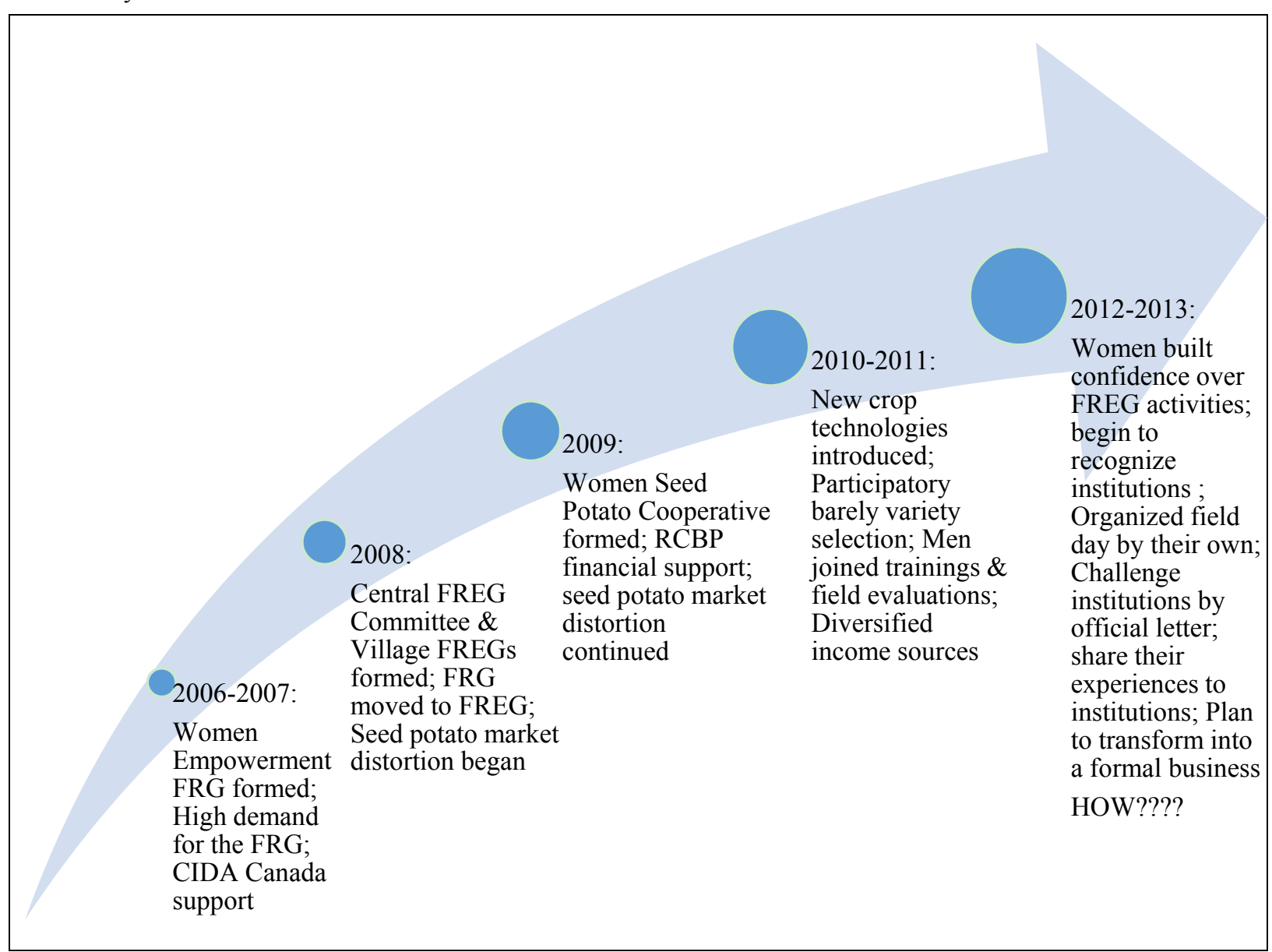

Figure 2. Timeline of major events of the participatory processes from 2006 to 2013 


\section{Results and Discussion}

\subsection{Technical Innovations}

The main entry point for initiating the FRG was introducing disease tolerant potato varieties with the objective of producing quality seed tubers. The research team and farmers interacted in the course of processes and many issues were continuously emerging. Researchers demonstrated improved technologies with their recommended packages and farmers modified some of those recommendations based on their local circumstances and needs.

Table 1. Research-based technical interventions and farmer modifications in the processes, 2006-2013

\begin{tabular}{|c|c|c|}
\hline Agricultural Issues & Technical intervention & Farmer modification in the process \\
\hline $\begin{array}{l}\text { Need for higher value } \\
\text { enterprises (e.g., seed } \\
\text { potato production) }\end{array}$ & $\begin{array}{l}\text { Disease tolerant potato } \\
\text { varieties used as entry } \\
\text { points. }\end{array}$ & $\begin{array}{l}\text { Farmers replaced disease intolerant local potatoes } \\
\text { often grown in homestead areas and reduced their } \\
\text { dependence on subsistence cereal production. Potato } \\
\text { has become one of their main outfield crops. }\end{array}$ \\
\hline $\begin{array}{l}\text { Average } \quad \text { potato } \\
\text { productivity }\end{array}$ & $\begin{array}{l}29-45 \mathrm{t} / \mathrm{ha} \text { in the main } \\
\text { production season. }\end{array}$ & $\begin{array}{l}\text { Farmers used to produce } 4 \mathrm{t} / \mathrm{ha} \text { in short season } \\
\text { production from local potatoes but now are able to } \\
\text { produce an average of } 22 \mathrm{t} / \mathrm{ha} \text { in the main production } \\
\text { season using improved seed potatoes. }\end{array}$ \\
\hline $\begin{array}{l}\text { Spacing between rows } \\
\text { and plants }\end{array}$ & $75 \mathrm{~cm}$ X $30 \mathrm{~cm}$ spacing. & Farmers modified the spacing to $90-100 \mathrm{~cm}$ X $30 \mathrm{~cm}$. \\
\hline Potato fertilizer rate & $\begin{array}{l}195 \quad \text { DAP \& } 165 \\
\text { UREA=360 kg/ha. }\end{array}$ & $\begin{array}{l}\text { Farmers applied more than } 360 \mathrm{~kg} / \mathrm{ha} \text { fertilizer with a } \\
\text { proportion of } 260 \mathrm{~kg} \text { DAP } / \mathrm{ha} \& 100 \mathrm{~kg} \text { UREA } / \mathrm{ha} .\end{array}$ \\
\hline Furrowing & $\begin{array}{l}\text { Make furrows and ridges } \\
\text { against slopes. }\end{array}$ & $\begin{array}{l}\text { Farmers make furrows and ridges along slopes in } \\
\text { order to drain excess water from plots. }\end{array}$ \\
\hline Diffused Light Store & Standard DLS model & DLS made from locally available materials \\
\hline Diversification & $\begin{array}{l}\text { Improved barely, } \\
\text { improved wheat and field } \\
\text { pea varieties. }\end{array}$ & $\begin{array}{l}\text { Farmers adopted some of the improved varieties as } \\
\text { complementary to seed potatoes. }\end{array}$ \\
\hline Technical trainings & $\begin{array}{l}\text { Experts } \quad \text { undertake } \\
\text { trainings. }\end{array}$ & $\begin{array}{l}\text { Farmers exercise trainings in the field and share their } \\
\text { experiences to fellow farmers. }\end{array}$ \\
\hline $\begin{array}{l}\text { Need for renewing old } \\
\text { potato varieties }\end{array}$ & $\begin{array}{l}\text { Renewed varieties were } \\
\text { offered to farmers by } \\
\text { HARC }\end{array}$ & Multiplying new seeds to use it for the following years \\
\hline Potato market problems & HARC provided trainings & Farmers took their own initiative to solve the problem \\
\hline Soil fertility problems & * & $*$ \\
\hline $\begin{array}{l}\text { Lack of improved dairy } \\
\text { cows }\end{array}$ & * & $*$ \\
\hline
\end{tabular}

Table 1 shows a description of agricultural issues that concern smallholder women farmers, research-based technical interventions and farmer modifications throughout the processes. The issues included were: the need for improved potato varieties, improved agronomic practices, post-harvest management, diversification options, technical trainings and emerging challenges. Farmers diversified seed potato production by complementary improved crop technologies that created alternative market and income sources for women smallholder farmers. Recently, farmers faced with new problems such as soil fertility decline and aging of potato varieties that require 
technical as well as institutional interventions.
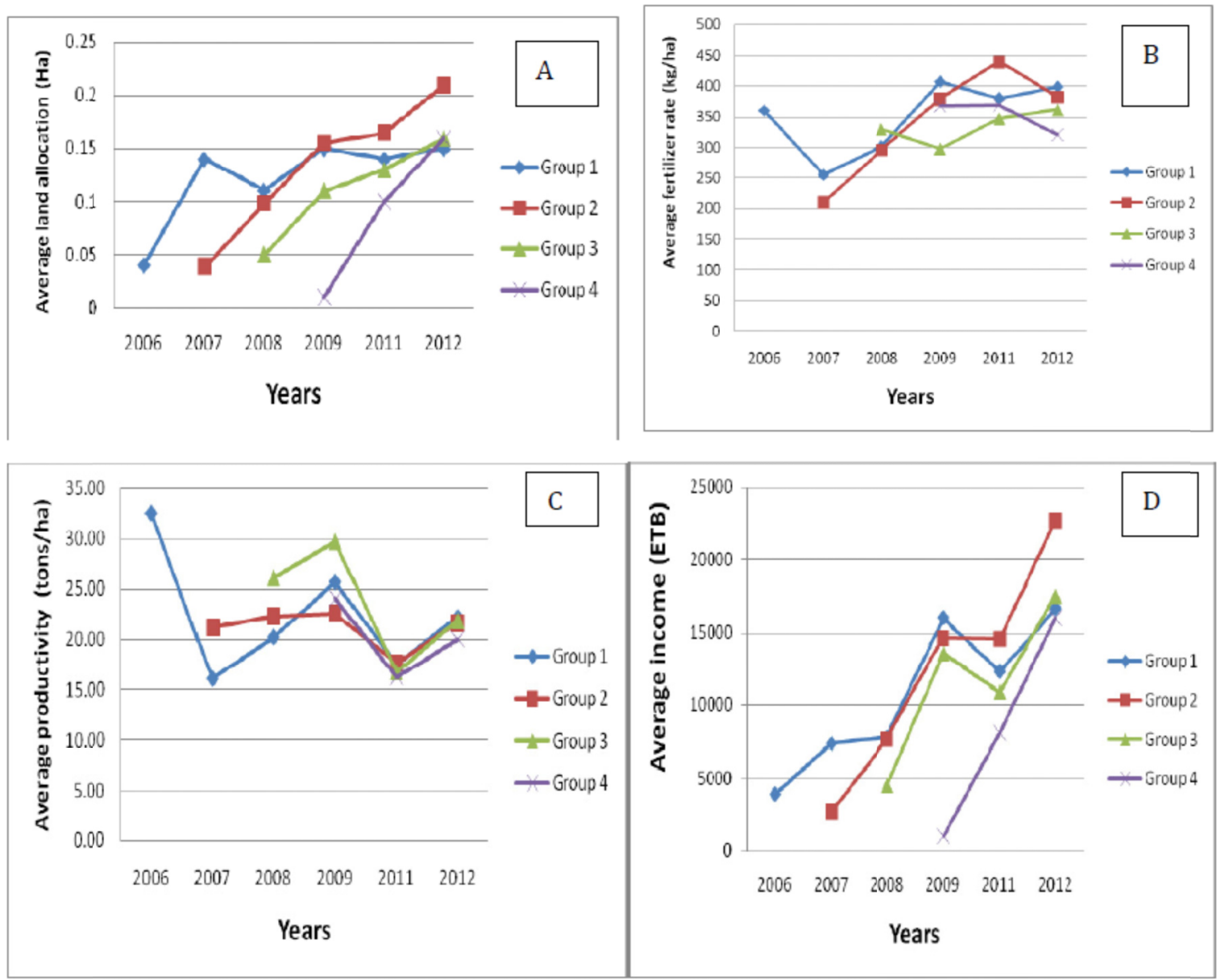

Figure 3. Production and economic performance of different women groups between 2006 and 2012 cropping years: Average land allocation to potatoes, (A); Average inorganic fertilizer rate application, (B); Average potato productivity, (C); and average income from potatoes by the different groups of women farmers, (D). Note: the year 2010 was excluded from this analysis as potato production in this cropping year was devastated by late blight disease.

Figure 3 shows a synthesis of production and economic performance of women farmers groups that joined the processes in four consecutive batches. Women farmers that joined the FRG process in 2006, 2007, 2008 and 2009 were reffered as Group 1, Group 2, Group 3 and Group 4, respectively. There were differences among the different groups of women farmers in both production and economic performance although the general trends were similar. The results clearly indicated that average land allocation to potatoes by the four groups of women farmers sharply rose over the following years (Figure 3A). This was correlated with average incomes generated by the different groups (Figure 3D). Average inorganic fertilizer application increased at earlier years, and was slowly decreasing at later years (Figure 3B). This was also correlated with steadily decreasing potato productivity (Figure 3C). The results correspond with farmers' awareness of soil fertility decline and aging of potato varieties in the intervention areas. Overall, FRG women member farmers were able to increase their potato productivity up to an average of $22 \mathrm{t} /$ ha using the improved varieties. They were also able to generate income about an average of ETB11 000 per year from the sale of potatoes. However, before the intervention, farmers' average potato productivity was about $4 \mathrm{t} / \mathrm{ha}$ from local varieties and that was mainly grown around homestead areas. Potato has now become one of the main outfield crops grown for both home consumption and cash generation in the study area and surrounding it.

This is clear evidence that productivity gap between female and male farmers is often caused by differences in input use including improved seeds and tackling that gender gap would indeed generate significant gains for agricultural development and enormous benefits to the wider society (FAO, 2011). It appears that while a 
women-familiar (Note 3) technology is crucial as an entry point, it is necessary to acknowledge that women farmers' needs, skills and capacities will continue to change and hence guide subsequent interventions. Yet this notion has not been taken practically by a majority of development practitioners and many agricultural innovations are hardly accessible to poor rural women (Ashby et al., 2009; Wakhungu, 2010; FAO, 2011; ActionAid International \& others, 2012).

\subsection{Organizational Innovations}

The FRG intervention in the study area has passed a number of stages in group functions and management as well as linkages with some of the key stakeholders involved in the processes. Before initiating the FRG in Burkusame Gebiya Robe, different group approaches were tested around Holetta Agricultural Research Center. These were: (i) Individual Farmer Approach in which individual decisions are made in the processes, (ii) Group Approach in which collective decisions are made in the processes, and (iii) Group Approach in which both individual and collective decisions are made in the processes.

In the first approach, resources and benefits were individually decided and managed but agricultural experts provided technologies and agricultural knowledge. The approach has resulted in "unidirectional inactive participation" and often skewed to resourceful farmers whom the experts have good links with. There was a very limited knowledge sharing in the processes and it was not a preferred research and extension approach. It has been documented that working with individual farmers is more top-down and less decentralized process as compared to working with groups (Sanginga, Lilja \& Tumwine, 2001).

In the second approach, farmers pooled resources together in which they collectively decided and managed. Differences in livelihood asset status were not taken into consideration and as a result, the approach led to negative competition and conflicts in the group. Family members were also not happy to participate and hence only the household head was involved in the processes. This approach has been failed.

The third approach has been adopted by the women FRG members in our case area in which both individual and collective decisions are made. Farmers individually manage land, labour, inputs and production activities, whereas they collectively manage field-based trainings, field monitoring and evaluations, access to inputs and markets etc. The approach promoted interest-based interactive participation by member farmers as well as other stakeholders involved in the processes.

It is imperative to understand different group approaches and a typology of participations (Note 4) rural people make in decision-making processes (Sanginga et al., 2001; ICRA, 2013). Participations range from what Sanginga et al. (2001) refer "passive participation" in which rural people are instructed by authorities to "auto-mobilization" type in which rural people take their own initiative in the decision-making processes. However, the main challenge is how to broaden farmer participation from what appears to be "passive or consultative" type to the "auto-mobilization" type (Sanginga et al., 2001).

\subsection{Members Profile in the FRG Process}

The FRG intervention began with 25 women farmers, 20 of whom were female headed households in 2006/2007 cropping season. The criterion for being a member was open and not limited by resources availability and other wealth related factors. The premise was that it is possible to generate wealth through the FRG process and farmer innovation. Women smallholder farmers can join the group, exit or rejoin group as they wish.

Table 2. Membership status and number of participating women farmers in the FRG process

\begin{tabular}{llll}
\hline Cropping year & New members & Dropouts & Rejoining \\
\hline $2006 / 2007$ & 25 & 5 & 0 \\
$2007 / 2008$ & 72 & 27 & 7 \\
$2008 / 2009$ & 82 & 42 & 4 \\
$2009 / 2010$ & 40 & 20 & 2 \\
$2010 / 2011$ & 2 & 2 & 0 \\
$2011 / 2012$ & 13 & 0 & 0 \\
$2012 / 2013$ & 19 & 0 & 0 \\
Total & 253 & 96 & 13 \\
\hline
\end{tabular}


Table 2 shows members profile over seven cropping years, from 2006/2007 to 2012/2013. In the first year, there were only 25 women farmers that joined the FRG intervention process. In the second year, 72 new women farmers joined the FRG but were found to be unmanageable in the process. As a result, members discussed among themselves and with facilitators about the possibility of splitting the FRG into sub-FREGs. In the third year, another 82 new women members joined, which increased the cumulative number of members to 179 . Members decided that they should split into sub-FREGs and at the same time designed mechanisms of networking the sub-FREGs. The dramatic increase of members in each year initiated the transition from FRG to FREG with a more focus on the extension service function. The discussion was also about the possibility of forming women seed producers cooperative to overcome market related obstacles. However, this resulted in some women members to exit the group because they contested the importance of having two cooperatives in a household. This is because men are already members of the formal cooperative which deals with general input and output marketing for major agricultural commodities in the study area.

\subsection{The FREG Model in the Processes}

After long discussions among members and facilitators involved in the processes, village FREGs and a central FREG committee were established. The central FREG committee had 5 members and its key roles are to lead, organize and manage both technical and administrative issues. In addition, this committee does all the networking activities with other stakeholders involved in the processes. Village FREGs also had committees as well as member women farmers. The village FREG committees ensure village level technical support to members; undertake quality inspection and data management.

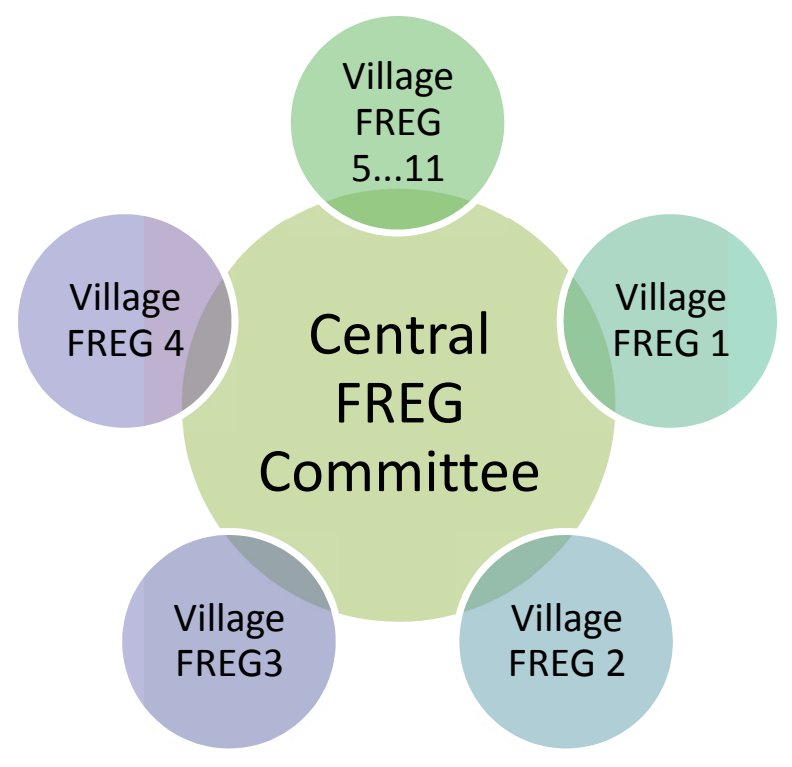

Figure 4. FREG model in the study area in which 11 village FREGs are networked by a central FREG committee drawn from nine villages in the kebele

Until this paper was written, there were 11 village FREGs drawn from nine villages in the area (Figure 4). Numbers of women member farmers in each village FREG ranged from 11-35 or an average of 23. The total numbers of women member farmers in the 11 village FREGs were 253 - networked with each other by the central FREG committee. This has been an impressive strategy in order to promote women collective action 
and/or their social capital - an essential capacity to create conducive conditions for empowering them and identify their own production constraints and opportunities (Rugumamu, 2014). This has also been identified as "bridging social capital" (Heemskerk \& Wennink, 2004; Dahal \& Adhikari, 2008). For instance, if there are 1000 farmers, it means that they can easily be networked with four central FREG committees. This would be a novel approach to create a large mass of farmer research and extension networks in the region and beyond. The approach, undoubtedly, enhances effective sharing of knowledge/experiences between farmers and promotes the transition of FRG-based innovations into formal groups, which is recently identified as a key challenge in Ethiopia (Dawit, 2013).

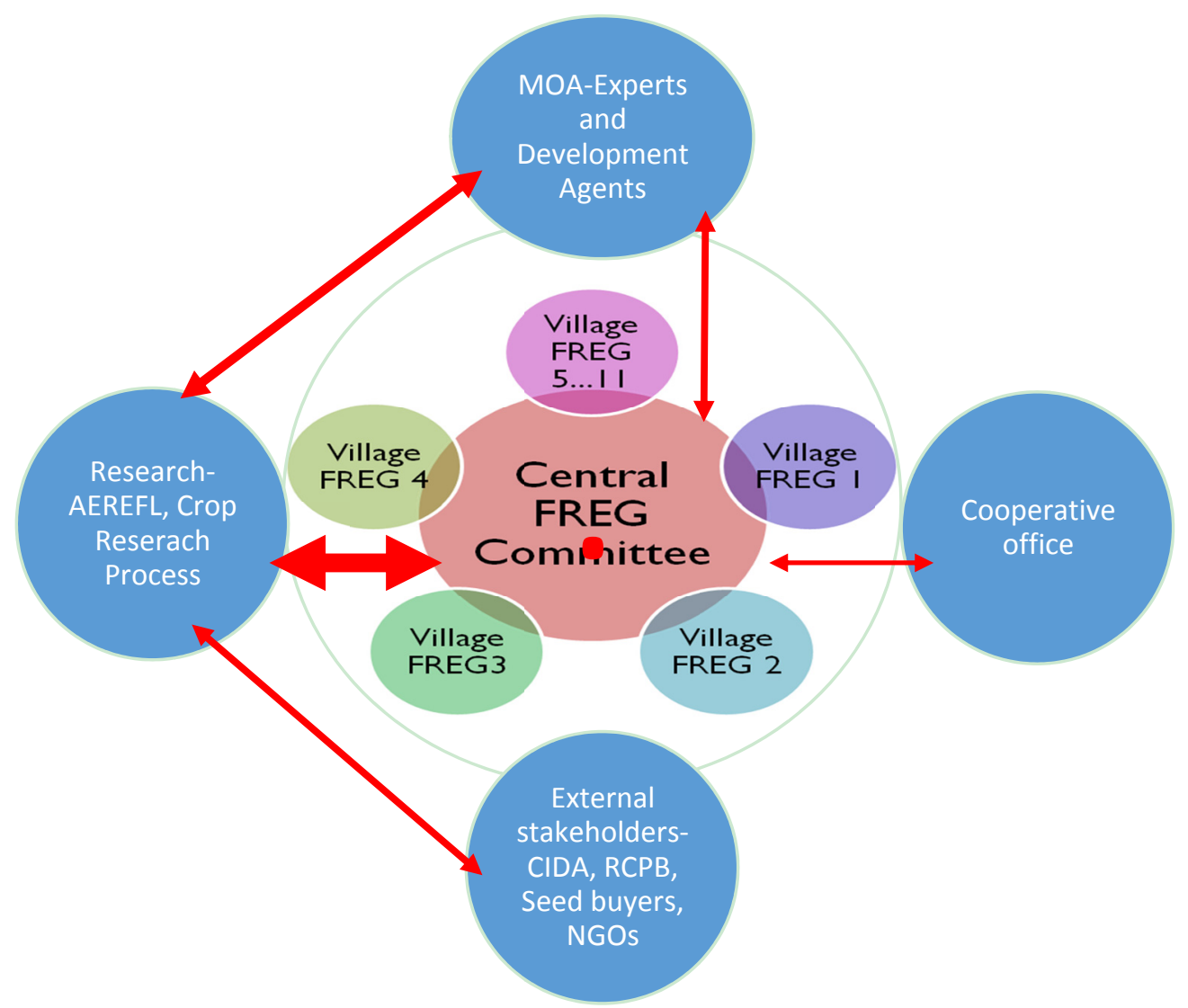

Figure 5. Functional linkages between key stakeholders involved in FRG intervention processes

\subsection{Functional Linkages between Stakeholders in the FREG Model}

Figure 5 shows key stakeholders linked through the central FREG committee, which is located at the center of the figure. The linkage platform has created effective communication and experience sharing among farmers, extension workers, researchers and external stakeholders. However, the degree of links depends on participation levels by each stakeholder involved in the processes. The thicknesses of the arrows in Figure 5 indicate the level of links between each stakeholder as perceived by women farmers (the primary actors of the intervention). The link between research and women farmers was the strongest. The link between research and district level Ministry of Agriculture (MOA) was fairly good. The link between MOA and women farmers was perceived as weak and that of between the Cooperative office and women farmers was even weaker. However, there were no direct linkages between women farmers and the external stakeholders especially the seed buyers. This has resulted in seed potato market distortion and subsequently deteriorating quality seed production as well as group functioning in the processes. Enhancing these functional linkages would create opportunity for multi-stakeholder co-learning (Vermeulen, Woodhill, Proctor \& Delnoye, 2008; Bedru et al., 2009), so that women farmers can further innovate in the potato value chains for effective technology development, dissemination and linking farmers to markets. This multi-stakeholder co-learning is an important element to be researched well in order to contribute to gender equity in smallholder farming system (Najjar, Spaling, \& Sinclair, 2013). 


\subsection{Capacity and Control over Decision Making in the Processes}

Different stakeholders participated in decision making depending on their capacity and ability to undertake various activities in the processes. The activities were aimed at enhancing social capital, group organizing ability, participation, technology and knowledge dissemination, experimentation and sustainability of the FREG. These indicators were similar to criteria indicated for monitoring and evaluation of FRGs in SSA countries (Heemskerk \& Wennink, 2004) and also relate to the women empowerment measurement indicators in agriculture (Alkire et al., 2103).

Table 3. Capacities and control over decision making by key actors over years in the processes

\begin{tabular}{|c|c|c|c|c|c|c|c|c|c|c|c|c|c|c|c|c|c|c|}
\hline \multirow{2}{*}{\multicolumn{3}{|c|}{$\begin{array}{l}\text { Main activities and sub-activities in a } \\
\text { year }\end{array}$}} & \multicolumn{4}{|c|}{ Year 1} & \multicolumn{4}{|c|}{ Year 2} & \multicolumn{3}{|c|}{ Year 3} & \multicolumn{5}{|c|}{ Year 4} \\
\hline & & & I & $\mathbf{C}$ & $\mathbf{V}$ & $\mathbf{M}$ & I & $\mathbf{C}$ & $\mathbf{V}$ & $\mathbf{M}$ & I & $\mathbf{C}$ & $\mathbf{V}$ & $\mathbf{M}$ & I & $\mathbf{C}$ & $\mathbf{V}$ & $\mathbf{M}$ \\
\hline 今े & & Motivating new members & $\mathrm{x}$ & - & - & - & - & $\mathrm{x}$ & - & - & - & $\mathrm{x}$ & $\mathrm{x}$ & $\mathrm{x}$ & - & $\mathrm{x}$ & $\mathrm{x}$ & $\mathrm{x}$ \\
\hline bo & & $\begin{array}{l}\text { Transfer of technologies to } \\
\text { other villages }\end{array}$ & $\mathrm{x}$ & - & - & - & $\mathrm{x}$ & $\mathrm{x}$ & - & - & $\mathrm{x}$ & $\mathrm{x}$ & $\mathrm{x}$ & $\mathrm{x}$ & - & $\mathrm{x}$ & $\mathrm{x}$ & $\mathrm{x}$ \\
\hline$\dot{\bar{\omega}}$ & & $\begin{array}{l}\text { Collective input provision } \\
\text { (sprayer, chemical, fertilizer) }\end{array}$ & $\mathrm{x}$ & - & - & - & - & $\mathrm{x}$ & $\mathrm{x}$ & - & - & $\mathrm{x}$ & $\mathrm{x}$ & - & - & $\mathrm{x}$ & $\mathrm{x}$ & $\mathrm{x}$ \\
\hline 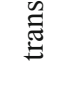 & & $\begin{array}{l}\text { Contribute to saving to enhance } \\
\text { finical capital of the group }\end{array}$ & $x$ & - & - & - & - & $\mathrm{x}$ & $\mathrm{x}$ & $\mathrm{x}$ & - & $\mathrm{x}$ & $\mathrm{x}$ & $x$ & - & - & $\mathrm{x}$ & $\mathrm{x}$ \\
\hline $\begin{array}{l}\text { कूर } \\
0 \\
0 \\
0 \\
0 \\
\end{array}$ & 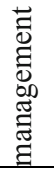 & $\begin{array}{l}\text { Agricultural planning, } \\
\text { coordination, evaluation and } \\
\text { group leadership }\end{array}$ & $\mathrm{x}$ & - & - & - & $\mathrm{x}$ & $\mathrm{x}$ & - & - & $\mathrm{x}$ & $\mathrm{x}$ & $\mathrm{x}$ & - & - & $\mathrm{x}$ & $\mathrm{x}$ & $\mathrm{x}$ \\
\hline 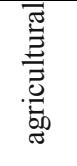 & & $\begin{array}{l}\text { Supervision and guidance of } \\
\text { new FREG members }\end{array}$ & $\mathrm{x}$ & - & - & - & $\mathrm{x}$ & - & - & - & $\mathrm{x}$ & $\mathrm{x}$ & $\mathrm{x}$ & $\mathrm{x}$ & - & - & $\mathrm{x}$ & $\mathrm{x}$ \\
\hline$\ddot{c}$ & & $\begin{array}{l}\text { Disease control and quality } \\
\text { management in the field }\end{array}$ & $x$ & - & - & - & $\mathrm{x}$ & $\mathrm{x}$ & $\mathrm{x}$ & - & $\mathrm{x}$ & $\mathrm{x}$ & $\mathrm{x}$ & $x$ & - & - & $\mathrm{x}$ & $\mathrm{x}$ \\
\hline 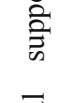 & & $\begin{array}{l}\text { Preliminary data collection and } \\
\text { field inspection }\end{array}$ & $x$ & - & - & - & $\mathrm{x}$ & $\mathrm{x}$ & - & - & - & $\mathrm{x}$ & $\mathrm{x}$ & $x$ & - & - & $\mathrm{x}$ & $\mathrm{x}$ \\
\hline 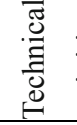 & $\cdot \stackrel{\substack{0 \\
:}}{:}$ & $\begin{array}{l}\text { Field visit and evaluation and } \\
\text { reporting to all FRG members }\end{array}$ & $\mathrm{x}$ & - & - & - & $\mathrm{x}$ & $\mathrm{x}$ & - & - & - & $\mathrm{x}$ & $\mathrm{x}$ & - & - & - & $\mathrm{x}$ & $\mathrm{x}$ \\
\hline
\end{tabular}

\begin{tabular}{|c|c|c|c|c|c|c|c|c|c|c|c|c|c|c|c|c|c|}
\hline. & Teaching member farmers & $\mathrm{x}$ & - & - & - & $\mathrm{x}$ & $\mathrm{x}$ & - & - & $\mathrm{x}$ & $\mathrm{x}$ & $\mathrm{x}$ & $\mathrm{x}$ & $\mathrm{x}$ & $\mathrm{x}$ & $\mathrm{x}$ & $\mathrm{x}$ \\
\hline $\begin{array}{l}3 \\
0 \\
0 \\
0 \\
0 \\
0\end{array}$ & $\begin{array}{l}\text { Search and invite experts for } \\
\text { training }\end{array}$ & $\mathrm{x}$ & - & - & - & $\mathrm{x}$ & - & - & - & $\mathrm{x}$ & - & - & - & $\mathrm{x}$ & $\mathrm{x}$ & - & - \\
\hline 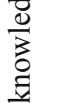 & $\begin{array}{l}\text { Organizing and leading } \\
\text { consultative meetings }\end{array}$ & $\mathrm{x}$ & - & - & - & $\mathrm{x}$ & $\mathrm{x}$ & - & - & $\mathrm{x}$ & - & - & - & $\mathrm{x}$ & $\mathrm{x}$ & - & - \\
\hline $\bar{\pi}$ & Field day organizations & $\mathrm{x}$ & - & - & - & $\mathrm{x}$ & $\mathrm{x}$ & - & - & $\mathrm{x}$ & $\mathrm{x}$ & $\mathrm{x}$ & $\mathrm{x}$ & $\mathrm{x}$ & $\mathrm{x}$ & $\mathrm{x}$ & $\mathrm{x}$ \\
\hline 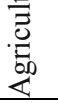 & $\begin{array}{l}\text { Evaluation of knowledge } \\
\text { sharing activities }\end{array}$ & $\mathrm{x}$ & - & - & - & $\mathrm{x}$ & $\mathrm{x}$ & - & - & $\mathrm{x}$ & $\mathrm{x}$ & $\mathrm{x}$ & $\mathrm{x}$ & - & $\mathrm{x}$ & $\mathrm{x}$ & $\mathrm{x}$ \\
\hline & Overall score & 14 & 0 & 0 & 0 & 11 & 12 & 3 & 1 & 9 & 12 & 12 & 9 & 4 & 9 & 12 & 12 \\
\hline
\end{tabular}

\section{Empowering Farmer Innovation}

Notes: I=Institutions; $\mathrm{C}=$ Central FREG Committee; V=Village FREGs Committee and $\mathrm{M}=$ Member women farmers 
Table 3 shows activities undertaken each year, capacities and decision making by the key actors for a period of four years since the first establishment of the FRG process. It was noted from the results that institutions (e.g., Holetta Agricultural Research Center) played key roles in implementing the activities during the early years of the FRG establishment. But in subsequent years, the central FREG committee took over some of the activities. Then village FREG committees adopted some responsibilities and finally member women farmers got capacitated and controlled decision making for most of the activities. Currently, formal institutions tended to focus on agricultural knowledge provision because different agricultural constraints continue to emerge throughout the processes. On the other hand, women farmers enhanced their collective capacity in disease control, follow up of seed quality, procure inputs, and undertake monthly meetings and decision making in the processes. This was clearly indicated by the overall score of activities undertaken each year. The scores indicate how the roles of institutions were taken over by the central FREG committee, then transferred to village FREG committees and finally adopted by member women farmers in the FREG. The results clearly indicate that the participatory FRG intervention empowered women farmers' innovation. Similarly, it has been proven that investing in skills of rural women can bring socio-economic empowerment and subsequently enhance decision making abilities of their livelihood choices (Gawaya, 2008; FAO, IFAD \& ILO, 2010). Despite clear evidence that empowering women can help tackle gender gaps, it has been argued that many development programs seem to be reluctant to adequately invest in gender-sensitive interventions (World Bank, 2007; Ashby et al., 2009; Wakhungu, 2010; ActionAid International \& others, 2012).

\subsection{Knowledge Sharing Mechanisms}

Women farmers noted knowledge and experience sharing as key advantages of working in a group. This has enhanced their social and human capital including their spouses and other adult family members in the household. For example, one member women farmer in the intervention will get about eight times field-based trainings, one or two research center-based trainings and at least one improved technology per year. This means that member farmers who participated for relatively more number of years will have a wealth of knowledge to be shared among themselves, their families as well as their community and even beyond. Knowledge sharing mechanisms in the processes included field-based trainings, field exchange visits, farmer-to-farmer information exchange, demonstrations, field days and monthly meetings (Figure 6).

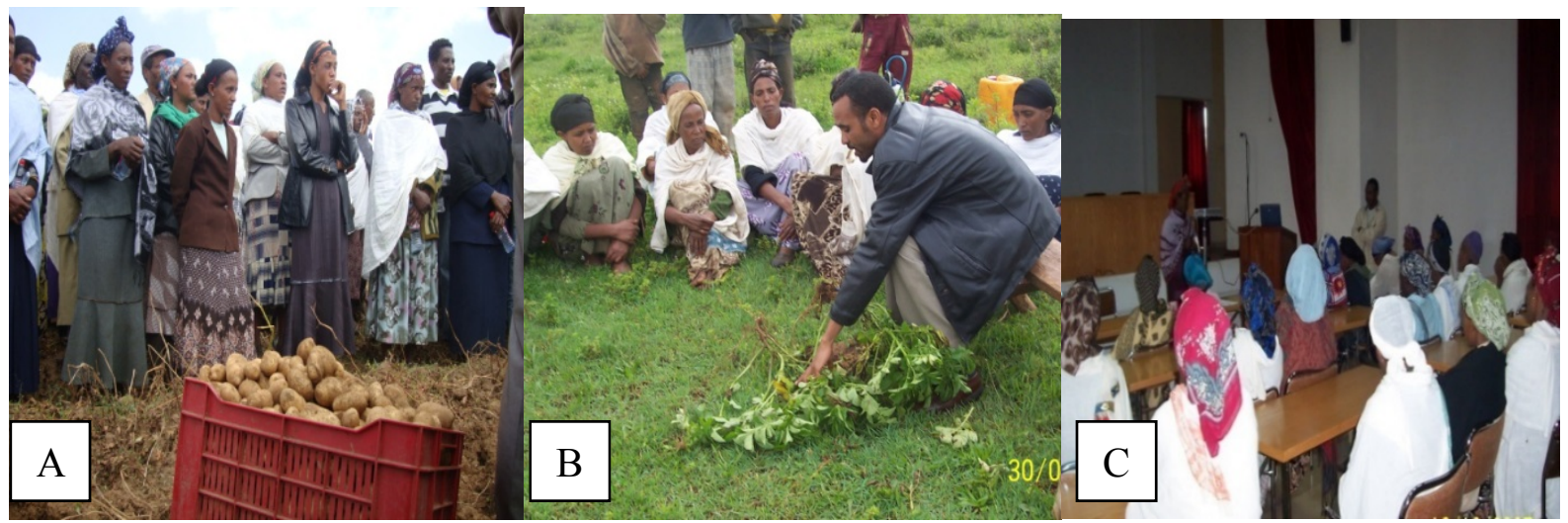

Figure 6. Women farmers demonstrating their potato seeds in a field day, (A); a field-based training being given by agricultural experts, (B); and research center-based trainings about potato technologies, (C)

\subsection{Market Related Issues in the Processes}

Women farmers were able to work in group, which has enhanced both their human and social capitals - individual and collective actions in the processes. They were successful in evaluating improved technologies and modifying them to their own local circumstances and needs; they were also able to disseminate the technology to other fellow women farmers; they were able to access seed potato markets and even established women seed potato producers' cooperative (Note 5). They sell seed potatoes to a number of seed buyers coming from the different regions of the country. Yet they often fail in the markets. There were enormous challenges including seed potato market distortions and market glut due to asymmetric market information in the region. It is imperative that women should get timely and accurate market information in order to benefit from output markets; unfortunately, men "commission agents" are exploiting them. Women farmers lack market information and unable to challenge "commission agents" who are exploiting them. Similarly, women often lose 
control of their enterprises to men when the enterprises become profitable (e.g., Ashby et al., 2009; Njuki, Kaaria, Chamunorwa, \& Chiuri, 2011).

Therefore, it is necessary to underline the importance of reliable output markets as an incentive to invest in agriculture. Strengthening marketing systems is crucial, for example, through the Participatory Market Chain Approach (PMCA) - a novel approach for triggering technological, institutional and commercial innovations (Bernet, Thiele \& Zschocke, 2006). The approach helps to create a room for co-learning and subsequently build trust among market chain actors including women farmers and men "commission agents". This would be feasible as women farmers have now moved into the production of higher value-market oriented seed potatoes rather than subsistence cereal production. In addition, they are on their way to transform into formal business although there are critical challenges which need further innovation in the areas of collective action. It is thus imperative that a better understanding of women's primary constraints (Tanwir \& Safdar, 2013); knowledge of gender norms in the specific local context (Quisumbing \& Pandolfelli, 2010), would better guide interventions that empower rural women and enhance their participation in economic activities which then pave their way in building their social capital (Heemskerk \& Wennink, 2004).

\subsection{Benefits from the FRG Intervention Process}

The benefits from the interventions were manifold. The primary beneficiaries were women farmers involved in the FRG. They were able to access improved technologies, markets and other extension services. Women farmers enhanced their experiences through frequent trainings and knowledge sharing activities. They have also shared their knowledge and experiences to their family and fellow farmers within and outside their community. They have become one of the seed potato sources to their nearby communities and even at national level. Member women farmers were also able to generate income for the household, which enhanced food security particularly during the months of July and October. These manifold benefits have indeed given them capacity to overcome poverty and food insecurity. Women are now able to send their children to schools and build more assets in the form of livestock. "Conflicts in a household that used to happen due to extreme poverty (i.e., before the FRG intervention) have now been reduced" as stated by one of the group member. Some women member farmers explained some of those benefits in box 1 and 2 .

Box 1: A woman respondent who participated for eight years in the FRG process:

"... Participating in the FRG is great for an easy access to training and knowledge sharing about improved practices. I have benefited and my livelihood has changed tremendously. For example, I sell to the market after sufficient home consumption even in times of food shortage months between July and October. In terms of cash, I was able to earn about ETB 8000 from the sale of seed potatoes in 2013. My decision making has also increased even in matters of resource use and other community issues...”
Box 2: A woman respondent who participated for six years in the FRG process:

“... Working in a group has several advantages particularly learning from each other and a better access to experts, technologies and market. Through the FRG intervention, I was able to grow disease tolerant seed potatoes and earn more income. As a result, the number of my livestock increased, I have built a house in town, bought cart for transportation, and I also hope to invest in improved dairy cows. I have secured my household food consumption and even preserved for the following year. I have generated about ETB 17,000 from the sale of seed potatoes in $2013 \ldots$,

It was very surprising that women farmers even have begun to challenge formal institutions, such as Holetta Agricultural Research Center through an official letter with their own stamp demanding new technologies and solutions to constraints of agricultural production and marketing. The letter written in local language outlined the role played by the research center since the establishment of the FRGs, and identified new problems that need technical and organizational interventions (See section 3.1). Women decision making in the household as well as in the community has tremendously enhanced. The case has proven that women farmers are productive farmers and can be empowered and capacitated easily if they can access improved technologies like the seed potatoes in our case. The results were consistent with women empowerment measurement indicators developed by Alkire et al. (2103) although this study has not rigorously quantified the indicators. Enabling women farmers to move 
beyond subsistence production and into higher-value market-oriented production is an element of successful agriculture for development strategies (World Bank, 2007). Unfortunately, there is a notion that different programs remain ineffective in promoting rural women's empowerment and participation in development initiatives (Gawaya, 2008; ActionAid International \& others, 2012; Tanwir \& Safdar, 2013).

The FRG intervention in Burkusame Gebiya Robe is now one of the model sites being visited by various guests from within the country and outside the country. It means that women farmers, who once have been neglected from the research and development agenda, are now sharing their impressive experiences. This has also been seen as a good image for the Ethiopian Institute of Agricultural Research (EIAR)/Holetta Agricultural Research Center and other stakeholders that have been continuously supporting the initiative. It has been documented in other areas that major development impacts achieved by group organizations that focus on benefits important to women (Ashby et al., 2009) and these impacts tend to reach the entire family (Minimol \& Makesh, 2012).

The initiative has attracted other groups of beneficiaries which the women farmers call them men "commission agents". This is because production and marketing of seed potatoes has created lucrative business in the central highlands of Ethiopia. While women farmers acknowledge the importance of legal brokers, they felt that "commission agents" are distorting the seed potato market without any value addition to the marketing chain. The benefits created through the intervention are also creating challenges to women farmers as well as to the entire seed potato value chain in the region. It appears that the three dimensions of social capital (bonding, bridging and linking) have been improved although in different degrees - bridging and linking aspects of their social capital need further improvements as compared to the bonding social capital (Dahal \& Adhikari, 2008).

\section{Challenges, Women Farmer Responses and Opportunities}

Table 4 highlights some of the key challenges in the intervention process, women farmer responses and some tangible opportunities available in the future. One of the main approaches revealed in the FRG intervention was empowering women farmers so that they can adequately respond to challenges they faced in the process. It was noted that farmers modified the technologies provided by researchers based on their own needs. They innovated in their group arrangement up to the formation of women cooperative. It appears that women farmers' problems were multi-faceted and their responses were also multidimensional. Their challenges relate to the three types of social capital, namely bonding (within group), bridging (between groups) and linking to the wider public-private agricultural innovation systems (e.g., Pretty, 2003; Heemskerk \& Wennink, 2004; Dahal \& Adhikari, 2008). It was clear that some of the problems were beyond the capacity of the farmers and hence require multi-stakeholder processes (Bernet et al., 2006; Vermeulen et al., 2008) and deliberate actions to be taken specific to women as a special group (Gawaya, 2008) in order to sustain the process. 
Table 4. Emerging challenges, women farmer responses and tangible opportunities

\begin{tabular}{|c|c|c|}
\hline Emerging challenges & Women farmer responses & pportunities \\
\hline $\begin{array}{l}\text { Market distortions and market } \\
\text { uncertainties in the seed potato } \\
\text { market. Men "commission } \\
\text { agents" have the upper hand to } \\
\text { decide in the seed potato } \\
\text { marketing chain. }\end{array}$ & $\begin{array}{l}\text { Women farmers established women } \\
\text { seed potato producers cooperative; } \\
\text { diversified into other crop } \\
\text { enterprises; and aim to strengthen } \\
\text { post-harvest seed potato inspection } \\
\text { by constructing a common DLS. }\end{array}$ & $\begin{array}{l}\text { Quality Declared Planting Material of Potato } \\
\text { has been put in the national seed legislation } \\
\text { system and can give power to the women } \\
\text { cooperative in collective decision making in the } \\
\text { seed potato system. }\end{array}$ \\
\hline $\begin{array}{l}\text { Lack of systematic } \\
\text { documentation of information } \\
\text { and sharing of process-based } \\
\text { results } \\
\text { Farmer-Researcher-Development } \\
\text { worker-Policy makers. }\end{array}$ & $\begin{array}{l}\text { Women farmers document some } \\
\text { level of information which is useful } \\
\text { for their decision making in the } \\
\text { seed potato market. }\end{array}$ & $\begin{array}{l}\text { Many institutions are valuing qualitative data/ } \\
\text { information sharing as necessary as quantitative } \\
\text { data. This would enhance process-based } \\
\text { qualitative information sharing among research } \\
\text { and development actors. }\end{array}$ \\
\hline $\begin{array}{l}\text { Unbalanced participation among } \\
\text { the different actors involved in } \\
\text { the FRG: Researchers, } \\
\text { technicians, MOA experts, } \\
\text { Cooperative office and member } \\
\text { farmers. }\end{array}$ & $\begin{array}{l}\text { Women farmers developed a } \\
\text { modality that combines incentives } \\
\text { through seed potato market with a } \\
\text { bylaw to keep members in the } \\
\text { process. }\end{array}$ & $\begin{array}{l}\text { This has been a nationally recognized problem } \\
\text { and initiatives are underway to institutionalize } \\
\text { the FRG approach and hence reorient } \\
\text { institutions to value interdisciplinary team work, } \\
\text { community work, flexible planning, and } \\
\text { inter-institutional co-investments/collaboration } \\
\text { which is of benefit to women farmers as well. }\end{array}$ \\
\hline $\begin{array}{l}\text { Difficulty to transform from a } \\
\text { FREG/Cooperative into a formal } \\
\text { business. }\end{array}$ & $\begin{array}{l}\text { Women farmers planned to } \\
\text { establish a shop in the area; engage } \\
\text { in fattening and other dairy } \\
\text { technologies; plan to link with ware } \\
\text { potato processors or wholesalers } \\
\text { when markets of seed potato fail. }\end{array}$ & $\begin{array}{l}\text { There is a national move to promote } \\
\text { cooperatives into formal businesses; The } \\
\text { Agricultural Development Partners Liaison } \\
\text { Advisory Council (ADPLAC) will be } \\
\text { strengthened to facilitate agricultural value } \\
\text { chains in the country and lead this business } \\
\text { transition. }\end{array}$ \\
\hline
\end{tabular}

\section{Conclusion}

The participatory seed potato management through FRG showed the effectiveness of targeted gender-sensitive intervention to empower women smallholder farmers in Welmera district of Ethiopia. Women farmers were able to produce and sell seed potatoes and this production and marketing has increased year after year ever since they have been established as FRG in 2006. The revolving seed initiative was a good strategy to easily attract new members to the process. Women farmers were able to access improved seed potato technologies and adapt to their own local needs and circumstances. They enhanced their skills and knowledge about improved agronomic practices, disease control, post-harvest management and even food preparation from potatoes. The skills and knowledge have been shared among member farmers through their group-based extension and farmer-to-farmer interaction. Intra and inter-FREGs knowledge and information sharing was very unique, which enhanced the bonding and bridging aspects of their social capital. They have also undergone various steps in group innovations including the formation of women seed producers' cooperative.

Apparently, women farmers were able to manage their resources wisely and enhanced their collective capacity to procure inputs and participate in output markets, which is even a challenge to the national agricultural extension 
system. They have also enhanced their capacity for collective action and were able to access inputs timely and adequately; able to produce enough food and earn cash from marketing the surplus that significantly improved their livelihoods. Currently, they are diversifying into higher economic-return farm and off-farm activities. Creating a more enabling environment in promoting their cooperative and facilitating their transitions into formal business is crucial in the future - relates more to the linking aspect of social capital. There is a need for replicating of this gender-sensitive approach in different regions and scaling up the process at national level. This will require more actors to join the process in order to tackle some of the emerging problems of women farmers in our study area and in different parts of the country. Policy makers should also take practical steps to ensure women farmers get equitable access to technologies, trainings, extension services, credits and resource sharing initiatives. Some of the key lessons learnt are described below:

The FRG intervention has been an evolving process. Women farmers have modified and will continue modifying methods and approaches to overcome emerging challenges. Though the intervention was gender-sensitive at the beginning targeting only marginalized women farmers, lately it was recognized very crucial to engage men in the processes. This is because men are responsible for some of the field operations and can play key roles in tackling market related barriers. Interventions need to consider gender roles in agriculture even if their main focus is to empower women.

Networking of village FREGs by the central FREG committee can be an innovative extension approach, which helps to reach out many farmers with an effective knowledge and experience sharing among member farmers and other actors. The experiences indicate the feasibility of promoting FRG-based innovations into formal groups and institutionalizing the FRG approach at national level. Working with effective groups is also a decentralized process that policy makers and development practitioners seek to achieve.

Although impressive results have been achieved in seed potato production and marketing, women continue to face new challenges and barriers related to entrepreneurship and transition into formal business groups. Re-orienting future trainings to enhance their entrepreneurship and business skills are crucial in order to overcome emerging market related challenges. Enhancing the bonding and linking aspects of social is indispensable.

Even though farmers developed a bylaw at the beginning of the intervention, the incentive or the benefit generated from the entry point technology (seed potato) was found to be more attracting and binding farmers in the process. Intervention programs should examine what kind of agricultural technology, e.g., crops can most benefit women including associated risks and tackling mechanisms.

Diversifying an entry point technology (seed potato) by other crops was vital to make the intervention sustainable. For example, in our case, the seed potato technology was followed by improved food and malt barely technologies, and then by improved wheat and pulse technologies. Diversification can create alternative market and income sources to overcome market risks and also ensures crop rotation options in order to respond to soil fertility problems in the area.

The FRG intervention not only brought economic empowerment for women but also enhanced decision making on household resources, at community level and even interacting officially with formal institutions. Gender-sensitive interventions would offer women to exist out of chronic poverty and subsequently to challenge underlying gender inequalities in the household as well as in the community.

The FRG intervention has practically shown the notion that women farmers have reproductive roles and not 'productive' farmers is not true. The case has proven that women farmers can be empowered to change their livelihoods. They can even become sources of knowledge and seed to their communities if they get appropriate training, technology, extension services and inputs as seen in this case study.

Knowledge transfer has been interactive and relatively faster for the women groups as they have already strong social bonds in the community - related to their cultural responsibilities. The lesson is that women can be very good extension agents if future initiatives could use this opportunity.

The FRG intervention required continuous engagement by the different stakeholders to keep the process moving. However, the engagement should change from an initial comprehensive support to facilitation roles in the areas of collective actions in market and targeted trainings as the process matures. It should lead to empowering farmer innovation in the process.

It is essential to strengthen the nutritional dimension of the process by diversifying dishes made from potatoes and combining with other household dishes. The monitoring and evaluation criteria of the seed production FRG can include nutrition monitoring in the process as well. 
Scaling out this type of gender-sensitive intervention is necessary. There is a need for properly documenting lessons from the process and sharing information with relevant extension workers. Scaling up of the intervention is also crucial in order to institutionalize the FRG approach at national level. It requires documenting lessons learnt from the intervention and substantiating it with a structured impact study using index-based quantitative indicators, such as the one developed by Alkire et al. (2103). It would then lead to a policy dialogue and trigger co-investment in agricultural development among farmers, scientists, development practitioners, donors and policy makers.

Finally, it is necessary to recognize in a process-based participatory research, no research method has absolute validity and hence triangulation of information is useful in order to overcome biases and inherent limitations of different methods.

\section{Acknowledgements}

We gratefully acknowledge the Canadian International Development Agency (CIDA) and Rural Capacity Building Project (RCBP) through the World Bank for their finical support. We thank women farmers in the study areas for sharing their experiences and useful information. We also thank Mr. Daniel Ayele for his continuous engagement in the process and for providing very useful information. We appreciate district level MOA staffs for their supports and engagement in the process. We also appreciate researchers at the Department of Agricultural Economics, Research Extension and Farmer Linkage (AEREFL) at HARC, Crop Research Process at HARC, HARC and EIAR management for strengthening member farmers in the process.

\section{Disclaimer}

The usual disclaimer applies to this paper.

\section{References}

ActionAid International, CARE, Christian Aid, Concern Worldwide, Find Your Feet, Oxfam, Practical Action, Save the Children, Self Help Africa. (2012). What Works for Women: Proven approaches for empowering women smallholders and achieving food security. London, UK. Retrieved from http://www.actionaid.org/sites/files/actionaid/what_works_for_women__final.pdf

Alemu, D. (2013). Possible Pathways of FRG advancement: FRGs beyond participatory research. Newsletter from FRG II. "R4F/FRG" No. 13. Retrieved from http://www.jica.go.jp/project/english/ethiopia/001/library/c8h0vm000000zu72-att/frg_130607.pdf

Alkire, S., Meinzen-Dick, R., Peterman, A., Quisumbing, A., Seymour, G., \& Vaz, A. (2013). The Women's Empowerment in Agriculture Index. World Development, 52, 71-91. http://dx.doi.org/10.1016/j.worlddev.2013.06.007

Ashby, J., Hartl, M., Lambrou, Y., Larson, G., Lubbock, A., Pehu, E., \& Ragasa, C. (2009). Investing in women as drivers of agricultural growth. In World Bank, FAO, IFAD. Gender in Agriculture Sourcebook. Washington, D.C.: World Bank. Retrieved from http://www.ifad.org/gender/pub/sourcebook/flyer.pdf

Ayele, S., Kuma, B., \& Nesha, K. (2008). Opportunities and challenges in accessing potato technologies among rural women. In Y. Chiche, \& K. Kelemu (Eds.), Gender differentials for planning agricultural research: Proceedings of the workshop on gender analysis in agricultural research held 27-29 November 2006 (pp. 89-98). Addis Ababa, Ethiopia: Ethiopian Institute of Agricultural Research.

Bedane, K., \& Kuma, B. (2002). Farmer participatory research: An overview. In G. Keneni, Y. Gojam, K. Bedane, C. Yirga, \& A. Dibabe, (Eds.), Towards farmers' Participatory Research: Attempts and achievements in the central highlands of Ethiopia. Proceedings of Client-Oriented Research Evaluation Workshop, 16-18 October 2001 (pp. 2-11). Holetta, Ethiopia: Holetta Agricultural Research Center.

Bedru, B., Berhanu, S., Endeshaw, H., Matsumoto, I., Niioka, M., Shiratori, K., Teha, M., \& Wole, K. (Eds). (2009). Guideline to Participatory Agricultural Research through Farmer Research Group (FRG) for Agricultural Researchers. Addis Ababa, Ethiopia: EIAR-OARI-JICA.

Bernet, T., Thiele, G., \& Zschocke, T. (2006). Participatory Market Chain Approach (PMCA)-User Guide. International Potato Center (CIP)-Papa Andina, Lima, Peru.

Dahal, G. R., \& Adhikari, K. P. (2008). Bridging, linking and bonding social capital in collective action. The case of Kalahan Forest Reserve in the Philippines. CAPRi Working Paper No. 79. International Food Policy Research Institute (IFPRI). http://dx.doi.org/10.2499/CAPRiWP79

FAO, IFAD, \& ILO. (2010). Investing in skills for socio-economic empowerment of rural women. Gender and 
Rural Employment. Policy Brief \#2. Retrieved from http://www.fao.org/docrep/013/i2008e/i2008e02.pdf

FAO. (2011). The State of Food and Agriculture: Women in Agriculture - Closing the gender gap for development. Rome: FAO. Retrieved from http://www.fao.org/docrep/013/i2050e/i2050e.pdf

Gawaya, R. (2008). Investing in Women Farmers to eliminate Food Insecurity in Southern Africa: Policy-related Research from Mozambique. Gender \& Development, 16(1), 147-159. http://dx.doi.org/10.1080/13552070701876367

Gildemacher, P. R., Demo, P., Barker, I., Kaguongo, W., Woldegiorgis, G., Wagoire, W. W., Wakahiu, M., Leeuwis, C., \& Struik, P. C. (2009). A Description of Seed Potato Systems in Kenya, Uganda and Ethiopia. American Journal of Potato Research, 86, 373-382. http://dx.doi.org/10.1007/s12230-009-9092-0

Heemskerk, W., \& Wennink, B. (2004). Building Social Capital for Agricultural Innovation: Experiences with farmer groups in Sub-Saharan Africa. Royal Tropical Institute (KIT) - Amsterdam. KIT Development Policy and Practice Amsterdam, The Netherlands. Bulletin 368. Retrieved from http://www.iscom.nl/publicaties/buildingsocialcapitalagriculture.pdf

Hirpa, A., Meuwissen, M. P. M., Tesfaye, A., Lommen, W. J. M., Lansink, A. O., Tesfaye, A., \& Struik, P. C. (2010). Analysis of Seed Potato Systems in Ethiopia. American Journal of Potato Research. http://dx.doi.org/10.1007/s12230-010-9164-1

ICRA (International Center for development oriented Research in Agriculture). (2012). ICRA Learning Materials: Participation in ARD - Key Concepts: Retrieved September 14, 2014 from http://www.icra-edu.org/objects/anglolearn/ACFwZGkKR.pdf

Lemaga, B. (2010). The potato value chain in sub-Saharan Africa with case study on Eastern Arica. In: FAO (2010). Strengthening potato value chains: Technical and Policy options for developing countries. Rome, Italy. pp 43-52.

Minimol, M. C., \& Makesh, K. G. (2012). Empowering Rural Women in Kerala: A Study on the Role of Self Help Groups. International Journal of Sociology and Anthropology, 4(9), 270-280. http://dx.doi.org/10.5897/IJSA12.003

Najjar, D., Spaling, H., \& Sinclair, A. J. (2013). Learning about Sustainability and Gender through Farmer Field Schools in the Taita Hills, Kenya. International Journal of Educational Development, 33(5), 466-475. http://dx.doi.org/10.1016/j.jijedudev.2012.06.004

Njuki, J., Kaaria, S., Chamunorwa, A., \& Chiuri, W. (2011). Linking Smallholder Farmers to Markets, Gender and Intra-Household Dynamics: Does the Choice of Commodity Matter? European Journal of Development Research, 23(3), 426-443. http://dx.doi.org/10.1057/ejdr.2011.8

Pretty, J. (2003). Social capital and connectedness: Issues and implications for agriculture, rural development and natural resource management in ACP countries. Review paper for CTA. CTA Working Document Number 8032. December 2003. Retrieved from http://internships.cta.int/pubs/wd8032/WD8032.pdf

Quisumbing, A. R., \& Pandolfelli, L. (2010). Promising Approaches to Address the Needs of Poor Female Farmers: Resources, Constraints, and Interventions. World Development, 38(4), 581-592. http://dx.doi.org/10.1016/j.worlddev.2009.10.006

Rugumamu, C. (2014). Empowering Smallholder Rice Farmers in Tanzania to increase Productivity for promoting Food Security in Eastern and Southern Africa. Agriculture \& Food Security, 3(1), 7. http://dx.doi.org/10.1186/2048-7010-3-7

Sanginga, P. C., Lilja, N., \& Tumwine, J. (2001). Assessing the quality of participation in farmers' research groups in the Highlands of Kabale, Uganda PRGA; CGIAR, Future Harvest. Working document/PRGA No. 19. Retrieved from http://ciat-library.ciat.cgiar.org/articulos_ciat/

Tafur, J. C., Hampson, K., Ingevall, A., \& Thijssen, R. (2007). Learning from experience: A manual for organisng, analysing and documenting field based information. The Netherlands: ILEIA.

Tanwir, M., \& Safdar, T. (2013). The Rural Woman's Constraints to Participation in Rural Organizations. Journal of International Women's Studies, 14(3), 210-229. Retrieved from http://vc.bridgew.edu/jiws/vol14/iss3/15

Tesfaye, A., Yirga, C., \& Bekele, T. (2002). Experiences of participatory research in the National Agricultural Research System of Ethiopia. In G. Keneni, Y. Gojam, K. Bedane, C. Yirga, \& A. Dibabe (Eds.), Towards farmers' Participatory Research: Attempts and achievements in the central highlands of Ethiopia. Proceedings of Client-Oriented Research Evaluation Workshop, 16-18 October 2001 (pp. 12-26). Holetta, 
Ethiopia: Holetta Agricultural Research Center.

van Niekerk, L., \& van Niekerk, D. (2009). Participatory Action Research: Addressing Social Vulnerability of Rural Women through Income-generating Activities. Journal of Disaster Risk Studies, 2(2), 127-146. http://dx.doi.org/10.4102/jamba.v2i2.20

Vermeulen, S., Woodhill, J., Proctor, F. J., \& Delnoye, R. (2008). Chain-wide learning for inclusive agrifood market development: A guide to multi-stakeholder processes for linking small scale producers with modern markets. International Institute for Environment and Development, London, UK and Wageningen University and Research Center, Wageningen, the Netherlands. Pp 114.

Wakhungu, J. W. (2010). Gender dimensions of science and technology: African women in agriculture. African Center for Technology Studies Policy Brief, September, 2010. Retrieved from http://www.un.org/womenwatch/daw/egm/gst_2010/Wakhungu-EP.2-EGM-ST.pdf

World Bank. (2007). Agriculture for development. World development report 2008. Washington DC: The World Bank.

\section{Notes}

Note 1. There are three major types of seed potato systems in Ethiopia, namely, the informal, the alternative and the formal (Hirpa et al., 2010). The informal seed potato system is the most dominant type, contributing about $98.7 \%$ of seed tubers used in the country, whereas the alternative seed system contributes about $1.3 \%$ of the seed potato supply in Ethiopia (Gildemacher et al., 2009; Hirpa et al., 2010). The formal seed system is just at its infant stage.

Note 2. Kebele is the lowest administrative unit in Ethiopia.

Note 3. Potato was grown mainly around homestead areas and hence women are more familiar with potato production activities than other outfield crops.

Note 4. According to Sanginga et al. (2001) and ICRA (2013), a typology of farmer participations include "informative/contractual, consultative, collaborate, collegial, and autonomous mobilization"; while the first two are nominal participations practically employing Transfer-of-Technology model with top-down characteristics, the last two show high level of farmer empowerment.

Note 5. Currently there are 95 active women members in the cooperative- managed by elected women farmers.

\section{Copyrights}

Copyright for this article is retained by the author(s), with first publication rights granted to the journal.

This is an open-access article distributed under the terms and conditions of the Creative Commons Attribution license (http://creativecommons.org/licenses/by/3.0/). 